\title{
Sacrilege, Tractarian Fiction and the Very Long Reformation ${ }^{1}$
}

\section{Alison Shell}

\section{Abstract:}

The Tractarian movement in the nineteenth-century Church of England brought new life to Reformation-era issues. One such was the notion of sacrilege, especially associated with Catholics and high-churchmen. Responding to reformist destruction of religious houses and the lay impropriation of monastic lands and revenues, believers in sacrilege asserted that those who damaged sacred objects or stole from the church risked divine displeasure. The seventeenth-century commentator Henry Spelman's writings on sacrilege were reprinted in the nineteenth century, and his warning that the descendants of impropriators would suffer for the sins of their ancestors was widely embraced. This essay examines how two Tractarian writers, John Mason Neale (1816-66) and Charlotte M. Yonge (1823-1901), engaged with ideas of sacrilege in their fiction.

Keywords: sacrilege, Tractarian novel, Sir Henry Spelman, John Mason Neale, Charlotte M. Yonge, dissolution of the monasteries, Gothic novel

A cursed family inherits an unwelcome legacy. History moves on, progress is made, enlightenment replaces barbarism and superstition, but still the curse -

\footnotetext{
${ }^{1}$ I am grateful to my mother, Jean Shell, for identifying the material on Yonge that inspired this article. Versions of it were delivered to the Charlotte M. Yonge Society in 2015 and to a panel at the Renaissance Society of America conference in 2018. My thanks to both audiences for their helpful comments; also to Arnold Hunt, David Loewenstein, Mark Rankin and the anonymous readers for their feedback on draft versions of this essay; and to Meghanne Flynn of Cambridge University Library.
} 
initiated by sacrilege, usurpation, or some unspecified dark deed - inexorably visits its punishment on successive generations. ${ }^{2}$

This quotation, from an influential monograph by Robert Mighall, describes how curses routinely shape Gothic fiction. But it also epitomises a real-life concern for Tractarians and their audiences throughout the Victorian period: that God would punish families who had benefited from the dissolution of the monasteries in sixteenth-century England, fulfilling the Old Testament threat that God would visit "the iniquity of the fathers upon the children unto the third and fourth generation." Augmented reprints of The History and Fate of Sacrilege by Sir Henry Spelman (1563/4-1641), originally compiled in the early seventeenth century, found a ready audience and became an inspiration for fictional plots. In another essay within this collection, James Simpson has argued for the "very long Reformation" as a way of approaching Victorian novelists' preoccupation with religion. The current essay develops his insight, examining how the fiction of two Tractarian novelists, John Mason Neale (1818-66) and Charlotte M. Yonge (1823-1901), offered present-day remedies for Reformation-era depredations. ${ }^{4}$

\footnotetext{
${ }^{2}$ Robert Mighall, A Geography of Victorian Gothic Fiction: Mapping History's Nightmares (Oxford: Oxford University Press, 1999), 80. See also Alison Milbank, Daughters of the House: Modes of the Gothic in Victorian Fiction (Basingstoke: Macmillan, 1992), and "The Victorian Gothic in English Novels and Stories, 1830-1880," chapter 8 in the Cambridge Companion to Gothic Fiction, ed. Jerrold E. Hogle (Cambridge: Cambridge University Press, 2002).

${ }^{3}$ Numbers 14:18: taken from The Bible: Authorised King James Version with Apocrypha, ed. Robert Carroll and Stephen Prickett (Oxford: Oxford University Press, 1997). See my Oral Culture and Catholicism in Early Modern England (Cambridge: Cambridge University Press, 2007), chapter 1.

${ }^{4}$ On Tractarian fiction, see S. A. Skinner, Tractarians and the 'Condition of England': The Social and Political Thought of the Oxford Movement (Oxford: Clarendon Press, 2004), 65-83; and Kirstie Blair,
} 


\section{Sacrilege and the Victorians}

The dissolution of religious houses under Henry VIII (r. 1509-47) reverberated for many centuries afterwards, not least in its widespread redistribution of property buildings, lands and tithes - to surviving ecclesiastical establishments or to lay people. ${ }^{5}$ A distinction was made between appropriations, where an ecclesiastical foundation took over property, and impropriations, where a lay person did. ${ }^{6}$ Impropriation was often felt to be the more offensive of the two practices, since it alienated property from the church altogether, and it inspired sacrilege narratives. ${ }^{7}$ If a farmer took stones from the local ruined abbey to build a barn and all his cows died,

\footnotetext{
"The Influence of the Oxford Movement on Poetry and Fiction," chapter 29 in The Oxford Handbook of the Oxford Movement, ed. Stewart J. Brown, Peter B. Nockles and James Pereiro (Oxford: Oxford University Press, 2017), which discusses Ayton Priory at 419-20. On the sacrilege narrative in earlier nineteenth-century fiction, see Roger E. Moore, Jane Austen and the Reformation: Remembering the Sacred Landscape (Abingdon: Routledge, 2016), chapter 4; for later periods, see the introduction to David Darvay, Haunting Modernity and the Gothic Presence in British Modernist Literature (Switzerland: Palgrave/Springer, 2016).
}

${ }^{5}$ See Alexandra Walsham, The Reformation of the Landscape: Religion, Identity, and Memory in Early Modern Britain and Ireland (Oxford: Oxford University Press, 2011); the work of the current AHRCfunded project "Remembering the Reformation" (see introduction to this special issue); and Harriet Lyon's essay in this special issue.

${ }^{6}$ This appears in legal writing from the seventeenth century onwards: Oxford English Dictionary, ‘impropriation', n. 1 a b; see also 'appropriation', n. 2.

7 “The very name is an indictment," the Victorian commentator W. Wyndham Malet (1803-85) remarked of impropriations: A Sermon Preached at St Michael's, Burleigh Street . . on the Occasion of the Annual Meeting of the Tithe Redemption Trust (London: Rivingtons, 1858), 10. The term "sacrilege narrative" denotes a cautionary tale describing the consequences of profaning sacred things or taking them away from their rightful owners: see Shell, Oral Culture, chapter 1. 
villagers might have opined that misfortune was only to be expected; if a landowner came into possession of impropriated church property, pundits would have remembered the circumstance if his bloodline failed or other disasters befell the family. Since a sacrilege narrative could be invoked to explain events that happened relatively near the time of the actual impropriations, or activated centuries afterwards to prove the inescapability of God's vengeance, it compelled backward glances at Reformation England, overriding any easy attempt at periodization.

Originating in oral tradition, gossip and anecdote, such stories often cropped up in family or local histories. A late Victorian example occurs in Julia Roundell's history of Cowdray House, a property owned by the Browne family from the sixteenth century. ${ }^{8}$ After the Dissolution of the Monasteries (1536-40), Sir Anthony Browne (c.1500-48), a favourite of Henry VIII, had received the spoils of Battle Abbey, Easebourne Priory and many other valuable grants of church property. ${ }^{9}$ It was widely believed that the family had been cursed by the sub-prioress of Easebourne Priory when she and her fellow religious were dispossessed by the king's commissioners, and that, as a result of the curse, they would suffer from fire and

\footnotetext{
${ }^{8}$ Succeeding heads of the family bore the title of Viscount Montague. See the family tree in Michael C. Questier, Catholicism and Community in Early Modern England: Politics, Aristocratic Patronage and Religion, c. 1550-1640 (Cambridge: Cambridge University Press, 2006), appendix 2; and Mrs. Charles (Julia) Roundell, Cowdray: The History of a Great English House (London: Bickers \& Son, 1884). On the ownership of the property, see also the entry for "The Ruins of Cowdray House," Historic England (database), no. 1277176, accessed 12 December 2018.

${ }^{9}$ Questier, Catholicism, appendix 1. Questier comments that "the names, for the manor, were interchangeable" (512).
} 
water. ${ }^{10}$ An especially interesting feature of this legend is the fact that the Brownes were one of England's most prominent Catholic families from the reign of Edward VI (1547-53) and for several centuries thereafter. ${ }^{11}$ Given that Protestant England had no obvious role for monastic communities, one can interpret the family's continued ownership of impropriated lands as a pragmatic wish to keep the faith while also retaining the spoils. ${ }^{12}$ But the stories surrounding their property and bloodline betray the tension this must have created in Sussex locality.

Rumours of a curse arose in the late eighteenth and early nineteenth centuries after a series of tragic events: the drowning of the eighth Viscount Montague on a trip to the Rhine in October 1793, a few days after Cowdray had been burnt to the ground, and a later boating accident in 1815 in which the heir and his brother perished with several family members. ${ }^{13}$ A local historian, writing in 1877 , takes a humorously

\footnotetext{
${ }^{10}$ The differing traditions are discussed in Roundell, Cowdray, 141-2. J. M. Neale's and Joseph Haskoll's edition of Sir Henry Spelman's History and Fate of Sacrilege, discussed below, transcribes curses on the spoliators of abbeys in Appendix 4.

${ }^{11}$ Anthony Joseph, the $7^{\text {th }}$ Viscount Montague, "the first of his family to forsake the Roman Catholic faith," was reconciled to it on his deathbed (Roundell, Cowdray, 92-5, quotation 92). The $8^{\text {th }}$ Viscount was brought up a Protestant (ibid., 100).

${ }^{12}$ Late in Mary I's reign (1553-58) Montague surrendered appropriated rectories in order to found chantries at Midhurst and Battle, though Elizabeth I's accession aborted the initiative (Questier,
} Catholicism, 113).

${ }^{13}$ See Roundell, Cowdray, especially chapters 10 and 13, and Questier, Catholicism, 10-11. The contemporary account of the tragedy in the Gentleman's Magazine is quoted by Roundell (108-9). After the death of George Samuel, the $8^{\text {th }}$ Viscount Montague, the title devolved on Mark Anthony Browne; when he died childless in 1797, the family became extinct in the male line. William Montague Browne and Courtenay John Browne, drowned in 1815, were the sons of Elizabeth Mary Browne, sister of the $8^{\text {th }}$ Viscount. 
sceptical attitude to the legend: "it should in fairness be remembered that the curse lighted upon them only after 200 years of honour and almost unbroken prosperity. How many of us might not be willing to disarm the Nemesis that dogs the footsteps of any persistent good fortune by stipulating to 'pay the bill' once only in every two centuries?"14 But a reminiscence of how the tragedy affected the eighth Viscount's mother points to the fatalistic mindset that such legends could instill:

Poor old Lady Montague never recovered from the shock of her son's death, and was continually haunted by the fear that her two grandsons would be drowned. "If they were out of her sight, she was always a prey to anxiety, especially if she knew they were near the river; and in her old age, when her powers were failing her, she would go to a large stone basin in the grounds and grope in it with her silver-handled stick, under the impression that her grandsons would be drowned there. 'Bessy', she would say to the housesteward's daughter, who often aided her failing steps, 'Bessy, I know it will come to them, as it came to my boy.' And then she would stand gazing at the weeds and floating water-lilies with a look of stony terror." 15 In the context of Roundell's volume as a whole, this is not just an affecting vignette. An anonymous piece appended to the history declares:

Church lands have never prospered in the hands of impropriators, and many a family dates its decadence from a careless acceptance of the fatal legacy, or from a covetous acquisition of what has once been and should still be the patrimony of the altar and the poor. Wherever restitution cannot be made, a

\footnotetext{
${ }^{14}$ Catherine Powlett, Duchess of Cleveland, History of Battle Abbey (London: William Clowes and Sons, 1877), 197; cf. Roundell's comments at 142.

${ }^{15}$ Roundell, Cowdray, 107-8.
} 
thinking Catholic will at least feel himself obliged in a special manner to make reparation to the Church, by aiding her needs in the locality from which he derives his confiscated wealth as far as he can, according to the intentions of the pious founders, in order to avert from himself and his heirs the curse which has certainly been incurred by the original spoliators, and which in many notable instances seems to have followed family after family with the avenging and mysterious scourge of God's inscrutable justice. ${ }^{16}$

As this suggests, reparations to the church were routinely advocated by those concerned to avert the consequences of sacrilege. Protestant high-churchmen of all stripes found considerable common ground with Catholics here, given that both parties held relatively elevated notions of consecrated space and of the priest's sacred

\footnotetext{
${ }^{16}$ The article, "The Story of a Curse," is signed "K. S." and described by Roundell as written "by a member of an old Roman Catholic family in West Sussex' (175). Subsequent page references are taken from the extracts given in Roundell. The original was serialised in the Roman Catholic journal The Lamp, Vol.XIV (1878-9) as follows: Chapters I-II: 317-20; Chapter III: 330-1; Chapter IV-V: 375-6; Ch.VI: 394-6. Not all runs of the journal are complete: this reference is taken from the British Library holdings, shelf mark P.P. 262 D. The author, who identifies herself as female (160), claims to be recounting a series of legends absent from written sources - "The Protestant local guide-books have omitted all mention of its most salient incidents, and the later members of the family were extremely jealous of their becoming known" (162) - but told to her in her youth by a Midhurst resident, one Mrs. Barlow, who had been employed in the Cowdray household (161-2). Timothy J. McCann demonstrates the lack of documentary evidence for an earlier story that the $5^{\text {th }}$ Viscount Montague (d. 1717) murdered his chaplain for refusing to grant him absolution, cited in the nineteenth century as demonstrating the Cowdray curse: "On the Alleged Murder of his Chaplain by Henry Browne, $5^{\text {th }}$ Viscount Montague of Cowdray," Sussex Archaeological Collections, vol.131 (1993): 126-8.
} 
role. But, inevitably, they disagreed on which church needed to be compensated. ${ }^{17} \mathrm{Sir}$ Henry Spelman, England's most influential post-Reformation writer on sacrilege, had after all been a conformist. Worn down by prolonged litigation over the leases of Blackborough and Wormegay Abbeys, which he had purchased from the Crown in 1594, he came to believe that his problems were incurred by meddling with sacred things: a conclusion which led him to conduct research into the issue, particularly in his local East Anglia. A comment in Spelman's treatise on the misuse of tithes sums up his views: "It is not then a worke of bounty and benevolence to restore these appropriations to the Church, but of duty and necessity so to doe." ${ }^{18}$ His writing had the virtue of setting out a comprehensive, conscientiously rigorous response to one of the English Reformation's more dubious legacies, which inspired several laypeople to return impropriations to the Church of England - if not to the Roman Catholics. ${ }^{19}$ Of Spelman's studies on the topic, The History and Fate of Sacrilege was the best-known in Victorian England. ${ }^{20}$ Inspired by the events of Henry VIII's reign,

\footnotetext{
${ }^{17}$ For Spelman's History of Sacrilege, see below, XXXX [pagination to be added at proof stage]. On impoverished incumbents of impropriated livings, see G. F. A. Best, Temporal Pillars: Queen Anne's Bounty, the Ecclesiastical Commissioners, and the Church of England (Cambridge, Cambridge University Press, 1964), 234-8.

${ }^{18}$ De non temerandis ecclesiis (1613 ed.), 86-7, STC 23067.2. This was re-edited in 1841 by Robert Jefferies Spranger: see Richard W. Pfaff, “John Mason Neale and 'Sacrilege': Spelman (1643) ReInvigorated," Journal of Ecclesiastical History, 66.3 (2015): 578-95 (at 583).

${ }^{19}$ Gerald Bray, "Canon Law and the Church of England," in Anthony Milton (ed.), The Oxford History of Anglicanism, Volume 1 (Oxford: Oxford University Press, 2017), chapter 9, at 181.

${ }^{20}$ Among the Victorians, Spelman was the best-known seventeenth-century commentator on the topic: for his contemporaries, see Shell, chapter 1, and Martin Dzelzainis, “'Undouted (sic) Realities': Clarendon on Sacrilege," Historical Journal 33.3 (1990): 515-540.
} 
conceived and researched in the 1620s and 1630s, unprinted till 1698, edited in 1846 and running through a number of reprints - the last as late as 1895 - its publishing history powerfully testifies to the idea of a very long Reformation: the more so because Spelman's Victorian editors, John Mason Neale and Joseph Haskoll (181971), were firm believers in the consequences of sacrilege. ${ }^{21}$ Appropriately for the time-bomb that it was, The History and Fate of Sacrilege was much less known in Spelman's lifetime than later; impugning the inheritances of several powerful families, it was a controversial compilation that did not see print till long after Spelman's death. ${ }^{22}$ As its editors were to discover, Spelman's arguments retained the power to cause offence in their own time.

In the preface to the second edition of 1853 - like the first of 1846, issued anonymously - Neale and Haskoll describe how, as they sought supplementary material, their informants were often unwilling to supply hard data:

\footnotetext{
${ }^{21}$ Pfaff, "John Mason Neale," identifies the editors and discusses reprints. Eleanor A. Towle, John Mason Neale, D.D.: A Memoir (London: Longmans, Green and Co., 1906), 128-9, records Neale’s and Haskoll's belief that the slow progress of the edition meant it was being diabolically hindered. I am grateful to Arnold Hunt for this reference.
}

${ }^{22}$ The History and Fate of Sacrilege was sent to the printers in 1663, delayed in the press, thought to be lost in the Fire of London and finally published in 1698 (Wing S4927). The volume's first editor mentions the contemporary rumour that initial publication had been stalled for fear of the offence the book would cause, quotes the preface of Spelman's collected works to the same effect, and speculates that their editor, Edmund Gibson (1669-1748), might have excluded it from the collection for “prudential Reasons": "But it has happen'd, that a true Copy of the Manuscript has now fall'n into the hands of (it seems) a less discreet Person, who will e'en let the World make what Use of it they please" (A4b). 
The four years that have elapsed since a new Edition was called for, will be found to have supplied new facts and fresh illustrations in the Annals of GOD'S dealings with the sacrilegious owners of that which is His. At the same time the Editors cannot but feel disappointed that so much should remain locked up in the traditions of private families, which the fear of shame, or notoriety, or scandal, prevents even such as recognise the finger of GOD in these judgments, from allowing to be made public. . . . Hints, - half anecdotes, - stories related under a promise of silence, [the editors] have received in plenty. ... Many of their informants seem to have profited by Hamlet's teaching, "by pronouncing of some doubtful phrase / as Well, well, we know; or, We could, an if we would; or, If we list to speak; or, There be, an if they might;" and the result has been, that their communications have been nearly useless (xix). ${ }^{23}$

There would have been good reason for such speakers to deal in Hamlet-like innuendo. Within the landed classes whose families had originally benefited most from impropriations, the topic must often have required considerable tact to address, not least to avoid impugning ancestors' behaviour. W. Wyndham Malet (1803-85) hints at this conflict in a sermon preached to the Tithe Redemption Trust: "Many of our dearest friends and relations are impropriators; ... But it is not a personal sin. They have inherited them" (15). ${ }^{24}$

\footnotetext{
${ }^{23}$ Hamlet, ed. Ann Thompson and Neil Taylor (London: Arden, $3^{\text {rd }}$ series, 2006), 1.5.173-75. In the same edition, data on Cowdray and Easebourne is given at 294-6. Pfaff, "John Mason Neale," 592-3, discusses the implications of anonymity.

${ }^{24}$ In the same sermon, Malet hopes for a time when the duty to pay tithes would be universally acknowledged, and hints at the possibility that sacrilege narratives could also be told of the trading
} 
A range of ethical quandaries thrown up by the inheritance and purchase of church property is surveyed in Neale's other major response to Spelman: his novel Ayton Priory: Or, The Restored Monastery (1843). ${ }^{25}$ Imaginatively rudimentary but ethically sophisticated, the novel is best seen as an example of what Kirstie Blair has called "didactic Tractarian fiction": its plot is there to provide occasions for searching conversational exchange, while character development is largely achieved through the presentation of different viewpoints. ${ }^{26}$ Predating Neale's edition of Spelman by three years, it contrasts the views of two neighbouring landowners, Sir John Morley and Colonel Abberley, whose estates include impropriations. ${ }^{27}$ The novel begins with Sir John's compunction over benefiting, as a lay rector, from tithes purchased by his grandfather and originally appropriate to Ayton Priory. As he tells his son Robert: 'Till lately, I had never bestowed much attention on the subject; or, if I ever felt a momentary scruple at enjoying a revenue which had once been solemnly appropriated to the service of GOD, I quieted my conscience by the thought that so long possession conferred a right ... [But] have I not been, in

\footnotetext{
classes: "and, brethren, should we then hear of such accidents as we now do by flood, by mine, by loom? Annually, how many hundreds of wrecks! . . . how many people ruined by banks breaking, and firms thrown down! - what can be firm unless blessed by God?" (15)

${ }^{25}$ On the relationship between edition and novel, see Michael Chandler, The Life and Work of John Mason Neale, 1818-1866 (Leominster: Gracewing, 1995), 24, 76, and Pfaff, esp. 582.

26 'Blair, "Influence," 412. Elisabeth Jay has commented of such novels that "the case they are intended to present proves more important than its imaginative embodiment": The Religion of the Heart: Anglican Evangelicalism and the Nineteenth-Century Novel (Oxford: Clarendon Press, 1979), 3.

${ }^{27}$ A reference to Ayton Priory in the 1846 Spelman edition was dropped in the second edition of 1853 , perhaps because it was felt to compromise the editors' continued anonymity (Pfaff, "John Mason Neale," 588).
} 
ignorance it is true, robbing GOD, and will not all that sum be required at my hands? The more I thought, and the more I read, the more sensible did I become of the danger of such an impropriation; and I can assure you that I quite trembled as I turned page after page of Sir Henry Spelman's “History of Sacrilege," and his "De Non Temerandis Ecclesiis." $(21,24)^{28}$

Newly sensible of the need to make reparation, Sir John forbids his daughter to marry Abberley's son and heir Charles because the family's recently purchased property includes the old priory buildings. But when Charles nearly dies as a result of a riding accident, his father has a change of heart, and resolves to restore the ruins and endow a monastery. ${ }^{29}$ Sir John lifts his objection to the match and initiates his own reparation by beautifying the local church, a project dear to the heart of any Tractarian. The happy ending combines marriage, restitution and restoration, suggesting that the bloodline will continue untroubled by God's wrath - and hinting too at the worldly anxieties which Victorian high-churchmanship helped to alleviate.

\section{Chantry House}

Charlotte M. Yonge almost certainly knew Neale and Haskoll's edition of Spelman, and was well aware of the issues that exercised them. The idea of restitution dominates her novel Chantry House (1886), set in a family seat built near a suppressed chantry chapel. ${ }^{30}$ A map and detailed description of the property is

\footnotetext{
${ }^{28}$ All references are taken from Ayton Priory: Or, The Restored Monastery (Cambridge: Deightons, 1843).

${ }^{29}$ On Tractarians' idealisation and advocacy of monastic life, see Skinner, Tractarians, 205-10. Chandler relates the novel to Neale's own convictions on this topic: John Mason Neale, chapter 4.

${ }^{30}$ The French translation was entitled La Restitution (Paris: Grassart, 1887). I am grateful to Charlotte Mitchell for this information.
} 
provided, from which we learn that the oldest portion of the house is built on fifteenth-century foundations, and that some of the chapel ruins survive in the garden (Figure 1). ${ }^{31}$ [Insert Figure 1 here, and proceed with text beginning "As the novel's narrator..." with no paragraph break]

\section{[Caption]}

Figure 1. Layout of property: illustration from Chantry House (London: Macmillan, 1905), 64.

As the novel's narrator Edward Winslow remarks: "We rejoiced in such a pretty and distinctive ornament to our garden, and never troubled ourselves about the desecration" (64). The comment recalls a moment in Ayton Priory when, early in the story, Abberley asks for Sir John's advice on landscape gardening, "with respect to a plan ... for giving better effect to the ruins," causing the latter to feel "the greatest repugnance towards discussing a design whereby an abbey was viewed only in the light of a picturesque ruin" (176). Yonge and Neale were tapping into the market for Gothic fiction, as the titles of both novels indicate. Yet they distance themselves from it too: critiquing the aesthetic pleasure in ruins associated with the genre, and forcibly reminding their readers of how the buildings came to be ruined in the first place. ${ }^{32}$

Chantry House provides a fictional counterpart to family histories of the kind discussed above; mimicking oral traditions of the kind that so infuriated Neale and Haskoll, it features a coda where the audience members record their comments on the main narrative. But the story is mostly told in the voice of Edward Winslow, the family antiquarian writing for his younger relatives, and couched as an old man's

\footnotetext{
${ }^{31}$ All references are taken from Chantry House (London: Macmillan, 1905).

${ }^{32}$ Ruth Bienstock Anolik, Property and Power in English Gothic Literature (Jefferson, NC: McFarland, 2016), chapter 4.
} 
nostalgic memories of the recent past. This narratorial distancing helps Yonge get away with the fact that Chantry House is a ghost story. The unquiet spirit in question is Lady Margaret, a member of the Fordyce family who married a Winslow in the early eighteenth century and was brutally treated, disappearing mysteriously and leaving rumours that her will, by which the house passed to the Winslow family, was composed under extortion. So far, so typical of Gothic fiction, in which abused women and female revenants are commonplace. ${ }^{33}$ Yet - and strikingly, given that Yonge is a female author - she is most interested in these themes as symptoms of a deeper underlying malady; no family who has the property will prosper until restitution is offered.

According to local tradition, the Winslow family is cursed. As newcomers to the neighborhood, they discover this when a dog belonging to the eldest son Griff attacks the cat of an old woman in the village, Dame Dearlove, who proceeds to berate him: “fine chap as ye think yourself . . . your time's coming. Look out for yourself. It's well known as how the curse is on the first-born. The Lady Margaret don't let none of 'em live to come after his father" (133). The family are unnerved enough to check the genealogy, and find that several first-born sons have indeed died. The deacon in charge of the parish, Mr. Henderson, talks with them about "ancestral sin and its possible effects" (134), mentioning the eighteenth chapter of Ezekiel,

\footnotetext{
${ }^{33}$ The literature on female Gothic and Gothic constructions of masculinity is considerable. For recent overviews, see Sherri L. Brown, Carol Sanf and Ellen J. Stockstill (ed.), A Research Guide to Gothic Literature in English (Lanham, MD: Rowman \& Littlefield, 2018), chapter sections on "Gender, Race, Sexuality and the Gothic"; and Diana Wallace and Andrew Smith (ed.), The Female Gothic: New Directions (Basingstoke: Palgrave Macmillan, 2009). As a manifestation of anxious masculinity, the topic of failed bloodlines deserves further analysis.
} 
which inveighs against rich men who oppress the poor; Edward describes the family's sense that "even in our own parish, the bitterness, distrust, and ingratitude were due to the careless, riotous, and oppressive family that we represented" (135). Thus, though curses reinforce the supernatural element in the story, they are also a more prosaic sign of hostility; the fact that they are uttered at all indicates that current family members need to be better neighbours than their forefathers. As this suggests, Yonge is most interested in Gothic plot-devices as a means of carrying moral freight.

Still, Griff does die before his time, and we are intended to believe in the ghost of Lady Margaret when it is sighted in the ruined chapel - a circumstance which heralds the eventual discovery of her will there. Though largely illegible, this is dated three years after the will by which the Winslow family inherited the property, and raises the question of whether the Fordyces are the rightful heirs. Clarence, the head of the family following the death of Griff and his father, keeps quiet about the implications until he can raise enough money, through a posting in China, to make restitution to the Fordyces. When he has the sum in hand, he explains the situation to Frank Fordyce, who responds:

Look here, my dear boy ... you have put me in a great fix. You have done the noblest deed at a terrible cost, and whatever I think, it ought not to be thrown away, nor you be hindered from freeing your soul from this sense of family guilt. But here, my forefathers had as little right to the Chantry as yours, and ever since I began to think about such things, I have been thankful that it was none of mine. Let us join in giving it or its value to some good work for God pour it out to the Lord, as we may say. (391)

Clarence and Frank establish an orphanage on the site, restoring the chapel for the benefit of the institution and surrounding households. As the renovation is taking 
place, a skeleton dating from Lady Margaret's time is discovered in the chapel ruins and assumed to be hers. As Edward relates: "On the ensuing night there was a strange, quiet funeral service at Earlscombe Church. ... the two Fordyces and three Winslows ... stood at the opening of the vault, and prayed that whatever guilt there might be should be put away from the families so soon to be made one" (400-1). He is referring to the impending marriage of Martyn Winslow and Anne Fordyce, which sets the seal on the restitution and the alliance.

Chantry House probes the foundations of literary Gothic more deeply than many other ghost-stories, disinterring its dual imaginative debt to the pre-Reformation church. On the one hand, the Gothic mode readily consigns Catholicism to the past. On the other, it is haunted by the poignancy of ruins and a consciousness of wrongs done: especially in England, where the remains of so many medieval Catholic foundations feature in the landscape, and where resentment must often have been felt towards families who benefited from ecclesiastical property. Yonge was committed both to fostering the Church of England's Catholic tradition and to upholding its establishment, and her fiction teases out the moral dubieties of this position. But she is less concerned with putting the clock back than with making restitution in the future. The ending of Chantry House, like that of Ayton Priory, taps into several of the Tractarian movement's concerns: its founding of religious and charitable foundations; its sympathetic advocacy of medievalism; and its related concern with ecclesiology, in particular the restoration and beautifying of religious buildings. ${ }^{34}$

\footnotetext{
${ }^{34}$ High-churchmen were often involved in local antiquarian and architectural societies: Nigel Yates, Anglican Ritualism in Victorian Britain, 1830-1910 (Oxford: Oxford University Press, 1999), 43-4.
} 
Yonge's correspondence testifies to her passionate interest in these issues and the ethical problems they raised. ${ }^{35}$

\section{The Pillars of the House: Restitution and Tragedy}

Like Chantry House, Yonge's The Pillars of the House (1873) tells the story of a bloodline and a property. The novel traces the history of the Underwoods, a gentry family who are badly off because they have been unjustly kept out of the family seat, Vale Leston Priory, by another branch of the family. Mr. Underwood dies young, and Felix, the eldest of his thirteen children, therefore becomes heir to Vale Leston Priory on the death of the old squire Fulbert Underwood's only son. On one level this represents a straightforward righting of wrongs, but since the property was once a religious house, Felix's succession to it heralds deeper issues of restitution. As with Chantry House, Yonge provides a map within the novel, demonstrating how closely the Priory and the church are connected. ${ }^{36}$ [Insert Figure 2 here, and then begin new paragraph with "When Felix becomes squire..."]

\section{[Caption]}

Figure 2. Layout of property: illustration from The Pillars of the House (London: Macmillan, 1901), vol. II, 256.

\footnotetext{
${ }^{35}$ Writing to Elizabeth Roberts (fl. 1852-59), for instance, Yonge comments favourably on the decision of the owner of the former Amesbury Abbey, Sir Edmund Antrobus, $2^{\text {nd }}$ Baronet (1792-1870), to prioritise repairs to the church over those to his family seat (14 August 1852: Charlotte Mitchell, Ellen Jordan and Helen Schinske (ed.), The Letters of Charlotte Mary Yonge (1823-1901), online at http://www.yongeletters.com/, 103).

${ }^{36}$ All references, except where otherwise mentioned, are taken from The Pillars of the House, 2 vols (London: Macmillan, 1875).
} 
When Felix becomes squire, he inherits a lay-rectorship: a problematic concept for anyone who has, as he does, high notions of the priestly calling. But even while disliking the idea, he sees how useful it could be as a temporary measure: the church has been neglected, part of the parish is no better than a slum, and the case for familial restitution seems clear. ${ }^{37}$ Since he is a layman himself, he conceives the notion of presenting his ordained younger brother Clement to the living. Though aware that Clement is relatively inexperienced, he muses: "it was dangerous to let the presentation pass by, since only a brother could satisfactorily co-operate in dealing with the old ancestral sacrileges, in case he should ever come in for the property himself" (II, 249). When the presentation takes place, the old squire is surprised to hear that Clement's full name is "Edward Clement" - Edward being the name of his father, who was dispossessed of the property earlier - and mutters "Strange it should so come about!” (II, 263). True to his Tractarian principles, Clement privately expresses his distaste at the patronage and his unease at benefiting from it - "I might be the veriest disgrace to my Orders for what they cared, so long as my name is Underwood!” - to which Felix gently replies: “And, Edward! . . I can't but be touched to see how the poor old man feels it an act of restitution. It is the best he knows, Clem, his first step, and I am glad you have not baulked him of it" (II, 265). In his last days the old squire is comforted by the knowledge that he has done what he can to right the wrong, which enables him to come back into the church. On

\footnotetext{
${ }^{37}$ The old squire expresses - in contrite but venal manner - the opinion that Felix should take orders himself: "It is not right the things should be separated. I've been crippled by it all my life, and cursed my folly in setting my face against the Church; and you'll hardly get the property in so good a condition as I did" (II, 258).
} 
his deathbed it becomes clear that he has never been a communicant, and that, as Clement puts it in a letter to Felix: "Latterly, the sense of wrong done to my father has held him back" (II, 276). Yet, "in dark doubt and dim trust and hope" (II, 282-3), he manages to receive the Eucharist on his deathbed, and the rite empowers him to articulate his repentance with more grace than he has managed hitherto:

The dying man made each brother give him his hand, and said, "Peace with all, isn't that it? You, both of you, Felix and Edward, I did use your father and mother as I ought not, though somehow I thought at the time I had the right, but I believe I have suffered for it all my life; and I ask your pardon as I would ask theirs." (II, 282)

Restitution to the family and to the church go together, and as the death-knell sounds for the old squire, the new one struggles with conflicting feelings: "To say that his first thought was not exultation would not be true ... though with it came the sense of responsibility, and of a perplexing knot to be untied, a knot of wrong to be undone at any - yes, at any cost' (II, 284-5, italics Yonge's). As the two brothers later stand at the churchyard gate and ponder their new responsibilities, their eyes turn to the cloister which connects the household with the church (285).

The situation confronting Felix when he inherits Vale Leston is well described in the words of the Bishop of New Zealand, George Augustus Selwyn (1809-78), preaching to the Tithe Redemption Trust in 1854:

If a man finds himself possessed by inheritance of property once dedicated to the service of God, what ought he to do? The law of the land protects him in his possession. ... It is true that it bears still the marks of dedication in its ruined chapel, now turned into a barn; its ancient font used as a trough for horses; its burial-ground furrowed by the plough; it is true, that in an age when 
all tithe is grudged, he may make it tenfold more hateful by rigid exaction, and by applying it to worldly uses: but all this is strictly legal; . . . why should a second reformation now be needed, to undo what the first reformation did? ... I ask for no alteration of the law - I leave that to Caesar - far less would I sanction any agrarian spoliation, or any dreams of socialism; but I would awake that ... inward judge of right and wrong, which tells us ... that what was once God's is God's for ever. ${ }^{38}$

The Pillars of the House is permeated by a similar attitude, thoroughly Anglican and owing much to Spelman: that the present ownership of this once-monastic property is an accomplished fact, ratified by law and custom, but that the family occupying it has an overarching duty to acknowledge its debt to the church. This view dictates Yonge's gaps as well as her emphases. Relatively little is made of the original monastic dispossession: initially a surprising omission, given that Yonge was imaginatively fired by medievalism and in favour of religious orders. But dwelling on it at length could have compromised the reader's view on the Underwoods' style of restitution, dedicated to upholding the established church, and it makes sense that her imaginative priorities should have lain elsewhere. One brief, sympathetically comic gesture towards the topic does come in the episode where a visitor, "Countess" Kate Caergwent, is shown round Vale Leston church; we are told of Clement, by this time the incumbent, that she "satisfied him (and more) by indignation on behalf of the monks - not sentimental, but evidently straight out of Dean Hook's version of the

\footnotetext{
${ }^{38}$ George Augustus Selwyn, Bishop of New Zealand, A Sermon, Preached at Christ Church, St Giles, on the Occasion of the Annual Meeting of the Tithe Redemption Trust, June 27, 1854, by the Right Reverend the Bishop of New Zealand (London: F. \& J. Rivington and John Leslie, 1854), 11-12.
} 
dissolution of the abbeys" (II, 413). ${ }^{39}$ Much rides on the narrator's parenthesis - the reader infers that Clement finds Kate's informed but undigested views a little sophomoric, and thereby understands how far Clement has come from his own younger days of callow Catholicising fervour.

It matters to Yonge's novelistic mission that Clement and his Anglicanism should mature as the novel progresses, morally legitimizing the control of a parish by the squire and his ordained younger brother. ${ }^{40}$ It becomes clear that Clement is wellsuited for the incumbency when he sees the local slum and feels moved to work there, musing to Felix: "it is plain that it is a call, though why - why it should have come to me, I cannot think." Felix replies, "Perhaps . . . because we are especially bound to fight against the evil our family has allowed to accumulate" (II, 267). While he means the old Squire's neglect of the parish, the reader is not allowed to forget the direct relationship between its parlous state and the misuse of church revenue - nor that, if the sins of the fathers are visited upon the children, the children still have the opportunity to make restitution. But even so, the property is reported to carry a curse with it. This is given a facetious cast in some of the family's banter: when Felix discusses with his sister Geraldine the question of whether they should move to the Priory or stay in town, given the claims on the property, Geraldine vows that she would rather live on bread and cheese in the country, and Felix jokes, "So had I . . if the manes of the Underwoods are appeasable" (II, 304). ${ }^{41}$ While the family are still

\footnotetext{
${ }^{39}$ i.e. Walter Farquhar Hook, dean of Chichester (1798-1875), whose views on the topic can be found in his Lives of the Archbishops of Canterbury, 12 vols (London: Richard Bentley, 1860-76), vol. 6. ${ }^{40}$ For a real-life example of this, see Owen Chadwick, The Victorian Church, 2 parts (London: Adam \& Charles Black, 1966-70), part 2, 153.

41 "Manes" = a Latin term for the souls of the deceased, often (as here) used in a domestic context.
} 
new in the house, Mr. Milwright, a local antiquary, comes to visit and tells the tale of a family ghost. The narrator comments, in what reads as a moment of relatively direct authorial intervention: "The bad conscience of some despoiling Underwood had probably led to the idea of a walled-up monk, whose phantom was accustomed to take his walks abroad, rattling a chain, under the pleasing name of Dobby" (II, 345). The flippancy carries a charge; we are not invited to believe in Dobby, but to see the story as a symptom of what needs to be put right.

The most specific element of the curse is that an Underwood should drown in every generation. This too is introduced into the novel with a mixture of antiquarianism and jokiness: when Felix warns the resident members of the family about the dangerous eddy in the river Leston, Clement quotes a rhyme - "To Leston and Ewe [the local rivers] / Underwood pays due" - and cites the local legend, adding "I suppose since the sacrilege." ${ }^{42}$ Felix asks him to prove it, and Clement describes how his research on registers and monuments has yielded one eighteenth-century Underwood who had been drowned, and one young woman betrothed to an Underwood: just enough tragedy to sustain a local legend, the detail shows Yonge's novelistic restraint. On hearing the rhyme, the light-headed Angela Underwood carols “A prophecy, a prophecy! . . What fun! I shall hold up my head more than ever, now that we have a saw of our own!" (II, 330). Angela's delight is the most ironic moment of the story, since it is she who brings about an accident on a family boat-trip through singing provocatively to some drunken youths, encouraging them towards aquatic horseplay that ends in disaster. When two Underwoods die as a result - the mentally disabled Theodore, and later Felix himself - the legend gains new potency.

\footnotetext{
42 "Pays due" recalls the idea of tithes.
} 
Sacrilege narratives commonly featured the drowning of sons and heirs. The story from the annals of Cowdray, quoted earlier in this article, is one example. As a West Country native, Yonge might well have known another: the melancholy history of the Courtenays, a family from Powderham in Devon who lost five male issue to drowning at various times. ${ }^{43}$ In this context the curse is especially portentous, and Yonge's plot-mechanics are at their most visible in the lead-up to the accident. Any seasoned reader of Victorian novels smells trouble in a passage such as the following:

A sapphire kingfisher darted across the arch [of the bridge].

"Halcyon days," said Felix.

“Oh no! Halcyon days precede storms."

"Maybe they give strength for them. Times like this are surely foretastes of perfect bliss."

"How does that prepare for storms?"

"Not only by calming nerves and spirits, but by giving some experience of the joy beyond - ay, and sense of love and confidence in Him who has made all so exquisite for our delight." (II, 474)

Thomas Hardy (1840-1928), another novelist who foregrounded the language and symbolism of impending doom, is a useful point of comparison. If Hardy had written The Pillars of the House, he would have relished the supernatural overtones, the irony and the tragedy of the plot - yet the idea that Felix, the most virtuous and selfsacrificing of all the Underwoods, should be the one to suffer and die, would probably have been deployed to demonstrate divine arbitrariness or absence. Yonge comes to an opposite, far more optimistic conclusion. In The Pillars of the House, the notion of

\footnotetext{
${ }^{43}$ History of Sacrilege, ed. Neale and Haskoll (1853 ed.), 278-9.
} 
supernatural atonement for sacrilege is very much to the fore, but Gothic creepiness is seen as less important - and indeed less interesting - than the moral use to which its workings-out can be turned.

Where, for educated Christian believers such as Yonge, might superstition end and providence begin? One distinction is surely this: superstitious individuals identify supernatural events with little thought as to how these might apply to their own lives, beyond the need to fend off evil. The apprehension of providence, on the other hand, consists in the conjunction of external event with the Christian's divinely guided response to it. This can be manifested through the behaviour both of those who experience providential accidents first-hand, and of those who are indirectly affected by them. Felix's accident and prolonged, painful death - handled as unsparingly as any in Victorian fiction - is a shock to the family and to the reader. But its knock-on effects on the Underwood clan are more positive than otherwise, at least in Yonge's terms. Angela, the contingent cause of the accident, repents deeply and discovers a vocation to the religious life as a result; Bernard Underwood, an incipient wastrel, is shocked into a sense of responsibility; and Stella, Theodore's devoted twin, feels free to marry once he is dead. Felix's fate, and his own reflection on the inevitability of blood restitution, is particularly germane to the novel's deployment of the sacrilege narrative: “[p]erhaps,” he says, “when one's forefathers have done a great wrong ignorantly, may be $[s i c]-$ it must come on some one. I have been struck by seeing how seldom the lay rectory has gone in the direct line' (II, 559). ${ }^{44} \mathrm{He}$ himself is a collateral heir, and his own death while unmarried and childless means that the estate will revert to the son of his deceased younger brother Edgar. Again Yonge is drawing

\footnotetext{
${ }^{44}$ One of Felix's last acts as squire is to return the lay rectory to the church (II, 594, 659).
} 
on Spelman, whose research proved to his own satisfaction that such breaks in succession were more likely to happen within families who had benefited from monastic impropriations in the past.

Spelman and Yonge are connected by a direct line of descent themselves: both are acutely sensitive to issues thrown up by the Reformation, intrinsic to the formation of the Church of England but playing upon its anxieties and faultlines. In The Pillars of the House, the sins of the fathers are visited on the children not just to the third and fourth generation after the Henrician Reformation, but right down to the mid-Victorian era - and perhaps further too, problematising Spelman's practical measures for making restitution to the church. Felix, whose very name recalls the idea of felix culpa [i.e. happy fall], presents himself as a conscious sacrifice: if not for all humanity, at least for the sins of his forbears. But his atonement throws up a disturbing question: when the individual who has done most to repair the familial wrong loses his life, how much restitution is enough? Yonge ventures no answer, and at the end of the novel the submerged threat to the Underwood succession remains, since the heir is under age and physically frail.

\section{Conclusion}

The phenomenon of the sacrilege narrative shows how Gothic novels were prefigured and influenced by real-life gossip and genealogical speculation. Conversely, from the mid-eighteenth century onwards, the commonplaces of Gothic fiction would surely have given a literary cast to many such anecdotes. Spelman's writings on sacrilege, composed during an earlier phase of Reformation and later championed by high-church authors both within and outside fictional contexts, show this interface between popular belief and fiction in their reception history. It has long been recognized how Gothic fiction foregrounds both the representation of 
Catholicism from a Protestant perspective, and occult belief-systems which would have been off limits for any orthodox Christian. Spelman and the novelists who drew on him oblige the recognition of Anglican ingredients within the genre's eclectic sourcing. Gothic fiction was, for Neale and Yonge, a pious exercise which furthered the reform of the established church. ${ }^{45}$

It is tempting to divide Gothic novels into two categories: those which invite one to believe in supernatural forces, and those - most famously Ann Radcliffe's The Mysteries of Udolpho (1794) - which are an exercise in demystification. But two of the novels discussed above, Chantry House and Ayton Priory, complicate this picture. They share a supernatural premise, but also - for those who accepted Spelman's account of problem and solution - a rationalizing agenda; vengeful forces are at work, but these can be easily banished by making restitution to the church. The Pillars of the House sets out a more disturbing version of the sacrilege narrative, since Reformation depredations may visit further consequences upon the Underwoods despite their best efforts. Yet Yonge is less interested in making her readers' flesh creep than in using the ideal of restitution to test the moral mettle of her characters.

As this essay has shown, sacrilege narratives inspired by events of the English Reformation were widely believed into the late nineteenth century. They would not be entertained within mainstream discourse today, whether religious or secular - but a

\footnotetext{
${ }^{45}$ For recent comment on the "Catholic Gothic" in fiction, see Victor Sage's double review of Maria Purves, The Gothic and Catholicism: Religion, Cultural Exchange and the Popular Novel, 1785-1829 (Cardiff: University of Wales Press, 2009), and Diane Long Hoeveler, The Gothic Ideology: Religious Hysteria and Anti-Catholicism in British Popular Fiction, 1780-1880 (Cardiff: University of Wales Press, 2014), in Studies in Religion and the Enlightenment 1.1 (2018): 13-16.
} 
twentieth-century fictional example shows how children's literature can extend the lifespan of evacuated beliefs. One of Yonge's most obvious heirs in the field of girls' fiction, Noel Streatfeild (1895-1986), utilised the theme in her novel Party Frock, published in $1946 .{ }^{46}$ Set just after the Second World War, Party Frock tells the story of a pageant mounted at the local great house, referred to as "the Abbey." Local legend has it that the monks, turned out of the Abbey in Henry VIII's time, cursed the building, prophesying that it would be plagued by fire and water until such time as it was returned to God's service. The Abbey has indeed suffered a number of fires and floods over the centuries, with the result that it has become uneconomical for the owners, Colonel and Mrs. Day, to continue living there. The pageant is intended to mark their departure and the sale of the Abbey. However, at the eleventh hour a rescue package is put together by the commanding officer of the GI regiment stationed locally, and the heroine Selina delivers the good news to the audience in the pageant's epilogue:

"[The Americans] have bought the Abbey as a hostel for the youth of America, so that they can visit here. . . Colonel and Mrs. Day will live in a few rooms and act as host and hostess. ... The Abbey, therefore, passes to a purpose the abbot and monks, dispossessed in the reign of Henry the Eighth, would approve. If a curse has rested on this place, it is lifted now." Was it

\footnotetext{
${ }^{46}$ See Anglican Women Novelists: Charlotte Brontë to P.D. James, ed. Judith Maltby and Alison Shell (London: Bloomsbury, 2019), introduction. Another mid-twentieth-century Anglican writer of children's fiction, Elizabeth Goudge (1900-84), addresses similar themes in The Little White Horse $\left(1^{\text {st }}\right.$ ed. London: London University Press, 1946).
} 
Selina's fancy or did she hear a sigh? A tired sigh, as if someone very old had worked too long and was glad to rest. ${ }^{47}$

Read against its Victorian ancestors, Streatfeild's novel demonstrates the sacrilege narrative's ebbing credibility. Restitution is made not by returning the property to the church, but by initiating a secularised version of monastic hospitality; Selina's uncertainty over whether she has heard anything hints that the idea of supernatural vengeance is barely plausible, even in children's literature. Yet Party Frock may not be the last sigh of the sacrilege narrative in British fiction. Even if direct lines of succession are extinct, such stories may yet yield collateral descendants; the imaginative stimulus they give has interminable potential, taxing the elasticity of the term "Reformation" to its utmost.

\footnotetext{
${ }^{47}$ Party Shoes (the title under which Party Frock was reprinted) (Oxford: Oxford University Press, 2001), 241. Streatfeild, who was brought up in Sussex $(O D N B)$, may have known the story of Cowdray.
} 